\title{
Isolation and selection of nitrifying bacteria with high biofilm formation for treatment of ammonium polluted aquaculture water
}

\author{
Phân lập và tuyển chọn vi khuẩn nitrate hóa hình thành màng sinh học để xủ lý \\ nước nuôi trồng thủy sản bị ô nhiếm ammonium
}

Research article

Hoang, Phuong Ha*1; Nguyen, Hong Thu ${ }^{1}$; Tran, Trung Thanh ${ }^{1}$; Tran, Thanh Tung ${ }^{2}$; Do, Lan Phuong ${ }^{3}$; Le, Thi Nhi Cong ${ }^{1}$

${ }^{1}$ Institute of Biotechnology, Vietnam Academy of Science and Technology, ${ }^{2}$ University of Science and Technology of Hanoi, ${ }^{3}$ Vietnam Academy of Traditional Medicine

\begin{abstract}
A biofilm is any group of microorganisms in which cells stick to each other and adhere to a surface by excreting a matrix of extracellular polymeric substances (EPS). The chemoautotrophic nitrifying bacteria hardly form biofilms due to their extremely low growth rate; however, biofilm formation of nitrifying bacteria trends to attach in carrier by extracellular polysaccharides that facilitate mutual adhesion, the forming biofilm is also beneficial in nitrogen removal in biological filter systems, especially in aquaculture water treatment systems. The microbial activity within bio-carrier is a key factor in the performance of biofilm reactor. Selection the nitrifier bacteria that biofilm formation and immobilization on the carrier for application in ammonium polluted water treatment technologies, especially in aquaculture is our research objective. Therefore, in this study, ten and six strains of ammonia oxidizing bacteria (AOB) and nitrite oxidizing bacteria (NOB) respectively were isolated from six different aquaculture water samples collected from Quang Ninh and Soc Trang. Basing on their high nitrification activity and biofilm forming capacity, six bacterial strains have been selected to take photo by scanning electron microscope (SEM) and carry out in 2 - liter tanks with and without carriers. As the results, the system with carriers (30\% of total volume) increased nitrogen compounds elimination efficiency from 1.2 times to 2 times in comparison with the system without carrier. Two representatives of ammonia oxidizing bacterial group (B1.1; G2-1.2) were classification based on characteristics and they were classified as Nitrosomonas sp. and Nitrosococcus sp.
\end{abstract}

Màng sinh học được hình thành tù̀ vi sinh vật nhò̀ các tế bào tiết ra các chất cao phân tử ngoại bào (EPS) và dính vào nhau đồng thời được gắn lên một bè̀ mặt vật thể lỏng hoặc rắn. Vi khuẩn nitrate hóa tụ dương có thể tạo ra màng sinh họ nhưng khá khó khăn do tỷ lệ sinh trương rất chậm của chúng. Tuy nhiên vi khuẩn nitrate hóa tạo màng sinh họ thường có xu thế bám lên giá thể nhờ sự gắn kết của các polisaccarit ngoại bào. Sự hình thành màng sinh học cũng là lợi thế để loại bỏ các hợp chất nito trong các hệ thống lọc sinh học, đặc biệt là trong các hệ thống xủ lý nuớc nuôi trồng thủy sản. Hoạt tính vi sinh vật cùng với giá thể sinh học là một yếu tố quan trọng để thực hiện trong các bể phản ưng màng sinh học. Trong nghiên cứu này, muc tiêu của chúng tôi là lựa chọn được các vi khuẩn nitrate hóa có khả năng tạo màng sinh học và cố định chúng lên giá thể để ưng dưng trong các công nghệ xư lý nước bị ô nhiễm ammonia đặc biệt là trong nuôi trồng thủy sản. Kết quả cho thấy, tù sáu mẫu nước nuôi trồng thủy sản khác nhau tù Quảng Ninh và Sóc Trăng, 10 chủng vi khuẩn oxy hóa ammonia $(A O B)$ và 6 chủng vi khuẩn oxy hóa nitrite (NOB) đã được phân lập. Dựa vào hoạt tính nitrate hóa và khả năng tạo màng sinh học của các chủng vi khuẩn phân lập được 6 chủng điển hình đã được lụa chọn để chụp ảnh kính hiển vi điện tử quét và được ứng dụng trong hai bể sinh học với dung tích 2 lít có chứa và không chưa chất mang (giá thể). Sau 7 ngày, hệ thống sinh hoc chứa giá thể (chiếm 30\% thể tích) có hiệu suất loại bỏ các hợp chất nito tăng hơn tù̀ 1,2 đến 2 lần so với bể sinh học không chứa chất mang. Hai đại diện của nhóm vi khuẩn oxy hóa ammonia (B1.1 và G2-1.2) đã được phân loại so bộ dựa vào một số đặc điểm sinh học và chúng đã được xác định thuộc chi Nitrosomonas và chi Nitrosococcus.

Keywords: aquaculture, biofilm, carrier, chemoautotrophic, nitrifier bacteria 


\section{Introduction}

Brackish water shrimp farming has developed with an increasing intenseve farming, productivity and output are constantly being raised, many processing factories to export the shrimp and shrimp export is become the largest exportable commodity in Vietnam, the annual average of over $\$ 2$ billion. However, frequent outbreaks of microbial diseases over the last few years and high risk. One of the main causes of disease that is causing environmental pollution increases, caused by excessive food and animal excretion discharged into the environment has formed the organic compounds and waste as fertilizer, including nitrogen pollution accounts for $30-40 \%$. Nitrifying bacteria were involved nitrification process to convert ammonia to nitrate via nitrite, then they are applied in ammonia polluted water treatment technology especially in aquaculture. Nitrification is widely used to remove ammonia from wastewater by biological oxidation. Wastewaters containing high concentrations of ammonia create environmental problems because ammonia may be toxic to aquatic organisms and can cause fertilization of lakes and reservoirs which leads to algal growth and eutrophication (Forgie 1988, Welander 1998). The overall biochemical process of oxidation of $\mathrm{NH}_{4}^{+}$to $\mathrm{NO}_{2}^{-}$, then finally to $\mathrm{NO}_{3}{ }^{-}$is known as nitrification. Nitrification is performed by the group of bacteria known as nitrifiers. The nitrifying process takes place in two steps and each step is carried out by a specific group of nitrifying organisms. The two microbes involved have been identified in many studies and are the aerobic autotrophic main genera Nitrosomonas and Nitrobacter (Reynolds, 1996). The reactions are as follows:

$2 \mathrm{NH}_{4}^{+}+3 \mathrm{O}_{2} \rightarrow 2 \mathrm{NO}_{2}^{-}+4 \mathrm{H}^{+}+2 \mathrm{H}_{2} \mathrm{O}+$ Nitrosomonas (AOB)

$2 \mathrm{NO}_{2}^{-}+\mathrm{O}_{2} \rightarrow 2 \mathrm{NO}_{3}^{-}+\operatorname{Nitrobacter}(\mathrm{NOB})$

AOB performs the first step by oxidizing ammonium to nitrite. NOB completes the oxidation by converting the nitrite to nitrate.

Total ammonia nitrogen is the critical factor in aquaculture systems as it accumulates in the system as a by-product of feed and animal excretion and it has direct effect on the health of aquatic animals. In young shrimp larvae, concentrations of non-ionic ammonia $\left(\mathrm{NH}_{3}\right)$ as low as $0.01 \mathrm{mg} / \mathrm{L}$ can result in mortalities besides causing pathological disturbances as well as depressing growth rates (Ostrensky and Wasielesky Jr., 1995; L-iu and Chen, 2004 ). Nitrite is also harmful to larvae as it causes reduction of hemolymph oxyhemocyanin (in Penaeus monodon) with concomitant increase in the partial pressure of oxygen (pO2) in hemolymph and reduced oxygen affinity (p50) (Cheng and Chen, 1995). However, it is less toxic than ammonia (Alcaraz et al., 1999) and, only under conditions of long term exposure the toxicity is found manifested (Wheaton et al., $1991)$ in the reared animals. Likewise, ammonia and nitrite toxicity in Macrobrachium rosenbergii adults and larvae have been investigated by various researchers (Chen and Lee, 1997; Cavalli et al., 2000; Naqvi et al., 2007). Nitrate is relatively harmless to the cultured aquatic organisms (Tomasso, 1994) and it has not been a limiting factor for Macrobrachium larval culture (Mallasen et al., 2004).
In biological ammonia removal systems nitrifying activity of bacteria suspended in seawater has been reported to be extremely low due to their slow growth rate and inhibition of nitrification by free ammonia and nitrite (Furukawa et al., 1993). However, immobilization techniques have been useful to overcome the situation and accordingly (SungKoo et al., 2000), fixed film nitrification biofilters are commonly used for ammonia removal in recirculation aquaculture systems (Wheaton et al., I994; Seo et al., 2001; Shnel et al., 2002). In such installations attached growth as biofilm offer several advantages over suspended culture based systems, such as handling convenience, increased process stability to shock loading and prevention of the bacterial population from being washed off (Fitch et al., 1998; Nogueira et al., 1998). Conventional fixed-film biofilters applied in aquaculture systems include: fluidized bed reactor, biological rotating contactor, trickling filter, submerged filter, and floating packed-bed reactor (Jewell and Cumming, 1990; Nijhof and Bonverdeur, 1990; Yang, Lin - sen and Shieh, 2001, Valenti and Daniels 2000; New 2002). New biofilter types being recently introduced to RAS include: moving bed reactor, three-phase fluidized filter, and hybrid biofilter. The significance of nitrifying biofilters in aquaculture has been reviewed well (Eding et al., 2006; Colt, 2006; Gutierrez-wing and Malone, 2006) and rating standards for these systems (Colt et al., 2006; Malone and Pfeiffer, 2006) are developed recently. Many of the submerged biofilters use crushed oyster shell, dolomite or coral ( $5 \mathrm{~mm}$ particles) as the filter media, but calcareous media contain an inexhaustible source of buffer material which slowly dissolves into the water. Therefore, plastic filter media which have no buffering capacity are often used in biological filters (Seo et al., 2001; Sandu et al., 2002). Biofilter selection influences capital and operating costs of recirculating aquaculture systems, their water quality, and even the consistency of water treatment (Summerfelt, 2006). A perfect biofilter would remove all of the ammonia entering the unit, produce no nitrite, and support dense microbial growth on an inexpensive support material that does not capture solids, require little or no water pressure or maintenance, and require a small footprint. However, no biofilter type commercially available has been found to meet all those objectives, nevertheless each one has its own advantages and limitations. A great deal of research has been conducted on the design and operation of major biofilters in aquaculture systems. In addition to the general reviews on characteristic advantages and simple engineering methods for commonly used biofilters (Wheaten et a1., 1994; Timmons et al., 2001), researchers have provided valuable information in terms of system design, operation and performance evaluations on fluidized bed reactors (Sandu et al., 2002; Summerfelt, 2006), floating bead filters (Golz et al., 1999; Malone-and Beecher, 2000), trickling filters (Kamstra et al., 1998), and moving bed filters (Greiner and Timmons, 1998; Yossi Tal et al., 2003) for their applications in aquacultural systems. However, information on process mechanism and kinetics relative to nitrification biofilters applied to aquaculture systems is still insufficient. Simply employing data from traditional wastewater treatment processes to the design of aquaculture biofilters is not appropriate as nitrification conditions in aquaculture systems differs from domestic and industrial wastewater. Compared with domestic wastewater (Metcalf and Eddy Inc., 1991), aquaculture wastewater has a relatively low concentration of pollutants 
(Piedrahita, 2003). The nitrification rate is influenced by substrate concentration, dissolved oxygen (DO), mixing regime, $\mathrm{pH}$, temperature, salinity and the level of organics (Chen et al., 2006).

Therefore, our tasks are to detect autotrophic nitrifying bacteria group involved in converting nitrogen compounds in the environment, to study the biofilm formation of nitrifying bacteria and the effect of attached biofilm on the carrier in ammonium polluted water treatment system. This will lead to the preparation of the probiotics to thoroughly treat aquaculture water ammonium contaminated in $\mathrm{Vi}$ etnam.

\section{Material and method}

Samples: Six water samples were collected from aquaculture ponds in QuangNinh and SocTrang city, namely Bun, NuocVao, G1, G2, G3 and STII.

Microorganism culture media: Winogradsky (improve) I for AOB; II for NOB with inorganic carbon is $\mathrm{NaHCO}_{3}$ $(2 \mathrm{~g} / \mathrm{L})$ exchange $\mathrm{CaCO}_{3}(\mathrm{pH}=7.5)$ (Atlas, 1995).

Carrier: foam in size of $(1 \times 1 \times 1) \mathrm{cm}$ was utilized as carriers for immobilizing nitrifiers.

Enrichment of nitrifying bacteria: Microorganisms were enriched before isolation by continuous pump of oxygen and supplements of Winogradsky I medium $(100 \mathrm{mg} / 1 \mathrm{~N}$ $\mathrm{NH}_{4}^{+}$) without agarose in $7-10$ days before isolation.

Isolation of nitrifying bacteria: After enrichment, water samples were serially diluted to $10^{-1}, 10^{-2}, 10^{-3}, 10^{-4}$ and $10^{-}$ ${ }^{5}$ in penicillin vials. Subsequently, water sample from each vial was cultured on petri dishes of Winogradsky I and Winogradsky II medium by spread plating technique. Then, bacteria cultures were incubated at $30 \pm 2^{\circ} \mathrm{C}$ in $5-7$ days. After bacterial colonies could be observed by naked eyes, single colonies were sub - cultured on respective Winogradsky medium by streak plating technique. Subcultures were then incubated at the same conditions for $4-6$ days before further experiments.

Evaluation of nitrogen removing capability of bacteria isolates

\section{Nitrifying bacteria activity test protocols}

Nitrifying bacteria were grown in $20 \mathrm{ml}$ of liquid Winogradsky medium in incubator shaker ( $\mathrm{N}-$ Biotek) at 200 $\mathrm{rpm}, 30^{\circ} \mathrm{C}$. Starting concentration of nitrogenous compounds was $5 \mathrm{mg} / 1 \mathrm{~N}-\mathrm{NH}_{4}^{+}$or $5 \mathrm{mg} / 1 \mathrm{~N}-\mathrm{NO}_{2}^{-}$. After 5 days, culture media were withdrawn for activity test. All specimens were tested under the same condition.

\section{Activity test protocol}

Culture media were centrifuged at $10000 \mathrm{rpm}$ for 5 minutes. After centrifugation, cell pellets were removed to obtain supernatant. AOB activity was determined by the amount of $\mathrm{N}-\mathrm{NH}_{4}{ }^{+}$lost and $\mathrm{N}-\mathrm{NO}_{2}^{-}$formed by Nessler and Griss methods. NOB activity was determined by the amount of $\mathrm{N}-\mathrm{NO}_{2}{ }^{-}$lost and $\mathrm{N}-\mathrm{NO}_{3}{ }^{-}$formed by Griss and Salicylate methods.

Chemistry analysis methods: Determinate the ammonium concentration by Nessler, nitrite by Griss and nitrate by Brucine (Franson, 1995).

\section{Biofilm forming analysis}

Bacterial isolates were cultured in Winogradsky I or Winogradsky II liquid medium in a shaker incubator (200rpm, $30^{\circ} \mathrm{C}$ ) for 3 days, $1 \mathrm{ml}$ of culture media was transferred into aseptic Eppendorf tubes and cultured for 3 days (200rpm, $30^{\circ} \mathrm{C}$ ). Subsequently, all culture media were propagated into another set of Eppendorf tubes for bacterial growth determination (measure absorbance at $\mathrm{OD}_{600}$ ). The original tubes were stained with $1 \mathrm{ml}$ crystal violet $1 \%$ for 20 minutes at room temperature. After staining, sample tubes were washed gently with distilled water, $1 \mathrm{ml}$ of ethanol $70 \%$ was added to dissolve adhered crystal violet. Absorbance was measured at $\mathrm{OD}_{570}$.

SEM photographing: SEM photographing was performed at Vietnam National Institute of Hygiene and Epidemiology, department of Cell Metaphysics.

\section{Large - scale culture system of AOB and NOB together}

Bacteria isolates on agarose cultures were transferred to 2 systems of liquid media for evaluation of growth and activity in practice. One system did not contain carriers while the other contain foam ( $30 \%$ of total volume). Culture systems were maintained for 5 days with continuous supply of oxygen before any experiment.

\section{Results and Discussion}

\subsection{Isolation of nitrifying bacteria}

After being enriched the samples, that isolated and cultured on petri dishes and selected 10 single colonies on Winogradski I and 6 single colonies on Winogradski II different the phenotype, activity tests were performed for AOB and NOB.

\section{Nitrifying capacity of bacterial isolates}

After 5 days in shaker incubator bacterial, nitrifying activities were measured and demonstrated as the Table 1 following.

Table 1 shows that, all 16 isolated bacteria strains have nitrifying activity. In the ammonia-oxidizing group, the B1.1, B-1.3, B-2.2, G2-1.2 strains has higher ammonia oxidizing activity, another nitrite oxidizing group, the STSII2, ST-SII3 and ST-SII4 strains has higher oxidizing nitrite activity, which is potential for further study. 
Table 1. Activities of isolated bacteria

\begin{tabular}{|c|c|c|c|c|c|}
\hline \multicolumn{3}{|c|}{ Ammonia Oxidizing Bacteria } & \multicolumn{3}{|c|}{ Nitrite Oxidizing Bacteria } \\
\hline Isolate & $\begin{array}{l}\mathrm{NH}_{4}^{+}-\mathrm{N} \text { remain- } \\
\text { ing }(\mathrm{mg} / \mathrm{l})\end{array}$ & $\begin{array}{c}\mathrm{NO}_{2}{ }^{-}-\mathrm{N} \text { formed } \\
(\mathrm{mg} / \mathrm{l})\end{array}$ & Isolate & $\begin{array}{l}\mathrm{NO}_{2}^{-}-\mathrm{N} \text { remain- } \\
\text { ing }(\mathrm{mg} / \mathrm{l})\end{array}$ & $\begin{array}{c}\mathrm{NO}_{3}{ }^{-}-\mathrm{N} \text { formed } \\
(\mathrm{mg} / \mathrm{l})\end{array}$ \\
\hline Negative & 4.92 & Free & Negative & 5 & Free \\
\hline B- 1.1 & Free & 3.766 & ST-SII 2 & Free & 4.826 \\
\hline B- 1.3 & Free & 4.064 & ST-SII 3 & Free & 3.987 \\
\hline B- 2.1 & 1.262 & 3.427 & ST-SII 4 & Free & 4.923 \\
\hline B- 2.2 & Free & 4.297 & G1- 2.1 & 3.21 & 1.527 \\
\hline $\mathrm{G} 2-1.1$ & 2.657 & 2.153 & G2- 2.2 & 2.543 & 2.131 \\
\hline G2 -1.2 & Free & 4.510 & G3 -2.1 & 3.016 & 1.73 \\
\hline $\mathrm{NV}-1.2$ & 1.261 & 3.342 & & & \\
\hline NV- 1.1 & 1.115 & 3.597 & & & \\
\hline G1- 1.1 & 2.53 & 2.641 & & & \\
\hline G3 -1.2 & 3.114 & 1.877 & & & \\
\hline
\end{tabular}

\subsection{Biofilm formation of bacterial isolates}

Aside from determining activities of isolates, their biofilm formation was also studied. Based on the result of activity test, only six AOB strains and three NOB strains were tested for growth in liquid medium and biofilm forming capacity (Table 2).

Although all achieved bacteria could form biofilm, some isolates were not clearly visible. Thus, further testing and research are required. From Table 2, ST-SII 4 has the best biofilm formation, B-1.1, ST-SII2, G2-1.2, ST-SII3 and B1.3 had weaker biofilm forming capacity, however, they are still prominent for further study in large - scale culture system. By looking at Figure 1, the results from measuring absorbance correlate with naked eye observation. ST-SII 4 sample had the strongest crystal violet adhesion on Eppendorf tube while B-1.1, ST-SII2, G2-1.2, ST-SII3 and B-1.3 had less. Practical analysis showed that biofilm formation of isolated bacteria was reduced after 6 - 7 days in Eppendorf tubes. Further testing should be conducted to obtain specific data.

\subsection{SEM photographing of representative bacteria strain}

B-1.1, B-1.3, B-2.2, G2-1.2, ST-SII 2 and ST-SII4 bacterial strains were selected to photograph by Scanning Electron Microscope at Vietnam National Institute of Hygiene and Epidemiology (NIHE). Examples are shown in Figure 2-Figure 7.

Six bacteria strains different complete the phenotype (Figure 2-7), five out of six bacteria strains has rod or pear shape, the only exception cell of G2-1.2 strain is spherical shape. All of them appeared to have rough surface while surfaces of ST-SII4 were rough and slot. For rod - shaped bacteria, cell length varied from $1.15 \mu \mathrm{m}$ to $3.4 \mu \mathrm{m}$ while width was approximately 0.5 to $0.8 \mu \mathrm{m}$, for G2-1.2 strain, cell diameter ranged from $0.7-0.8 \mathrm{~nm}$, the characteristics of isolated bacteria strains shown thatAll of isolated bacteria strains has phenotype similarity to the bacteria of Nitrosomonas genus (follow Martin D et al., 2006) (Table 3).

Table 2. biofilm forming capacity of bacterial isolates

\begin{tabular}{llll} 
& \multicolumn{1}{r}{ Isolate } & OD 600 & OD 570 \\
\hline Negative control & 0.008 & 0.087 & \\
B-1.1 & $\mathbf{0 . 2 7 6}$ & $\mathbf{0 . 5 9 1}$ \\
B -1.3 & $\mathbf{0 . 1 1 3}$ & $\mathbf{0 . 3 8 9}$ \\
B -2.1 & 0.124 & 0.302 \\
B- 2.2 & 0.185 & 0.366 \\
NV- 1.1 & 0.085 & 0.279 \\
G2- 1.2 & $\mathbf{0 . 2 8 9}$ & $\mathbf{0 . 4 1 1}$ \\
ST-SII 2 & $\mathbf{0 . 2 3 6}$ & $\mathbf{0 . 4 7 5}$ \\
ST-SII 3 & $\mathbf{0 . 2 1 2}$ & $\mathbf{0 . 4 0 8}$ \\
ST-SII 4 & $\mathbf{0 . 4 1 8}$ & $\mathbf{0 . 7 1 0}$
\end{tabular}


Table 3. Characteristics of isolated bacteria strains

\begin{tabular}{|c|c|c|c|c|c|c|}
\hline Characteristics & B-1.1 & B-1.3 & B--2.2 & G2-1.2 & ST-SII2 & ST-SII4 \\
\hline Cell shap & $\begin{array}{l}\text { Long slender } \\
\text { curved rods }\end{array}$ & $\begin{array}{l}\text { Long straight } \\
\text { rods }\end{array}$ & Pear shap & spherical shap & $\begin{array}{l}\text { Slender pear } \\
\text { shap }\end{array}$ & Pear shap \\
\hline Cell size $(\mu \mathrm{m})$ & $0.5 \times 2.7$ & $\begin{array}{l}0.5-2,5 \times \quad 1.2- \\
3.4\end{array}$ & $0.5 \times 1.3$ & $0.7 \times 0.8$ & $0.4 \times 1.15$ & $0.8-1.5 \times 1-2$ \\
\hline $\begin{array}{l}\text { Surface of } \\
\text { cells }\end{array}$ & $\begin{array}{l}\text { Less rough } \\
\text { surface }\end{array}$ & $\begin{array}{l}\text { Less rough } \\
\text { surface }\end{array}$ & rough surface & rough surface & rough surface & $\begin{array}{l}\text { rough and slot } \\
\text { surface }\end{array}$ \\
\hline Growth & $\begin{array}{l}\text { cell dichot- } \\
\text { omy }\end{array}$ & $\begin{array}{l}\text { cell dichot- } \\
\text { omy }\end{array}$ & $\begin{array}{l}\text { cell dichot- } \\
\text { omy }\end{array}$ & $\begin{array}{l}\text { cell dichot- } \\
\text { omy }\end{array}$ & $\begin{array}{l}\text { cell dichot- } \\
\text { omy }\end{array}$ & $\begin{array}{l}\text { cell dichot- } \\
\text { omy }\end{array}$ \\
\hline $\mathrm{Hab}$ & $\begin{array}{l}\text { Brackish wa- } \\
\text { ter }\end{array}$ & $\begin{array}{l}\text { Brackish wa- } \\
\text { ter }\end{array}$ & $\begin{array}{l}\text { Brackish wa- } \\
\text { ter }\end{array}$ & $\begin{array}{l}\text { Brackish wa- } \\
\text { ter }\end{array}$ & $\begin{array}{l}\text { Brackish wa- } \\
\text { ter }\end{array}$ & $\begin{array}{l}\text { Brackish wa- } \\
\text { ter }\end{array}$ \\
\hline
\end{tabular}

Table 4. Characteristics and preferred habitats of the Nitrosococcus, Nitrosomonas genus and G2-1.2, B-1.1 species (Hans-Peter Koops et al., 2006)

Characteristis

Cell shape
Cell size $(\mu \mathrm{m})$
Salt requirement
Maximum salt toler-
ance (in mM)
Flagellation of
motile cells
Motion

Arrangement of
intracytoplasmic mem-
branes aximum ammonia
Maximu
tolerane $\mathrm{NH}_{4} \mathrm{Cl}$ (in
mN; pH 8.0 )
Preferred habitats

Sea water, brackish water and industrial wastewater treatment Plant.

\begin{tabular}{|c|c|c|c|}
\hline \multicolumn{4}{|c|}{ Genus } \\
\hline Nitrosococcus & G2-1.2 & Nitrosomonas & B-1.1 \\
\hline Spherical to ellipsoidal & Spherical shap & Straight rods & Slender rods \\
\hline $\begin{array}{l}1.5-1.8 \times 1.7-2.5 \\
\text { obligate salt require- } \\
\text { ment }\end{array}$ & $0.7 \times 0.8$ & $0.7-1.5 \times 1.0-2.4$ & $0.5 \times 2.7$ \\
\hline $100-1800$ & 600 & $150-900$ & 600 \\
\hline Tuft of flagella & Not observed & $\begin{array}{l}\text { Polar to } \\
\text { subpolar }\end{array}$ & $\begin{array}{l}\text { Polar to } \\
\text { subpolar }\end{array}$ \\
\hline $\begin{array}{l}\text { Motile cells possess a } \\
\text { tuft of flagella }\end{array}$ & Not observed & $\begin{array}{l}\text { Some cells motile; } \\
\text { some cells has not } \\
\text { observed }\end{array}$ & Not observed \\
\hline $\begin{array}{l}\text { Central stacks } \\
\text { of vesicles }\end{array}$ & $\begin{array}{l}\text { Central stacks } \\
\text { of vesicles }\end{array}$ & $\begin{array}{l}\text { Peripheral } \\
\text { flattened vesicles }\end{array}$ & $\begin{array}{l}\text { Peripheral } \\
\text { flattened vesi- } \\
\text { cles }\end{array}$ \\
\hline $500-1000$ & 600 & $50-600$ & 600 \\
\hline
\end{tabular}

Brackish water Sewage disposal Brackish water plants; eutrophication; freshwaters; fertilized soils. or Brackish water

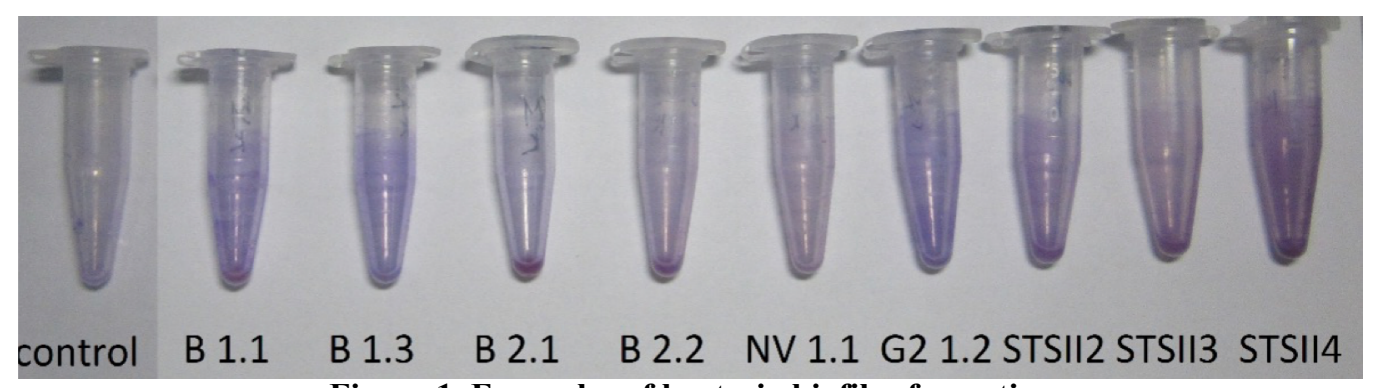

Figure 1. Examples of bacteria biofilm formation

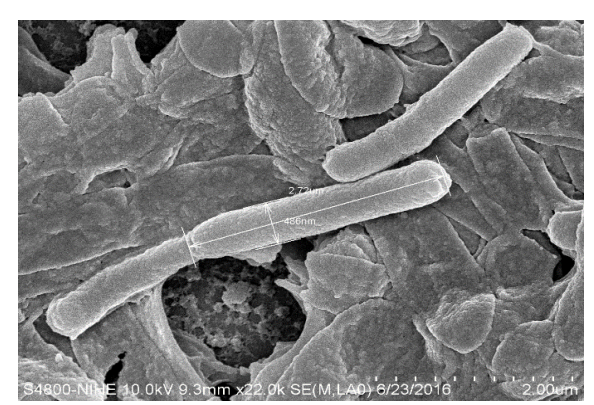

Figure. 2. B- 1.1

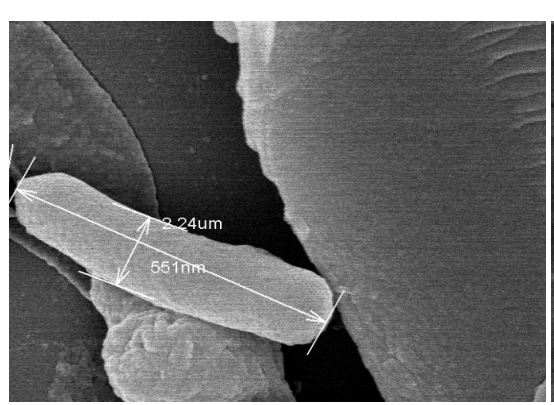

Figure 3. B-1.3

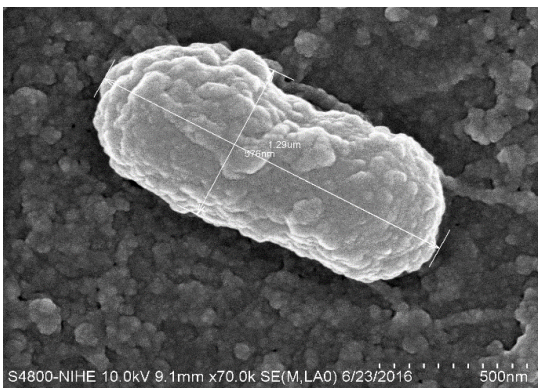

Figure 4. B-2.2 


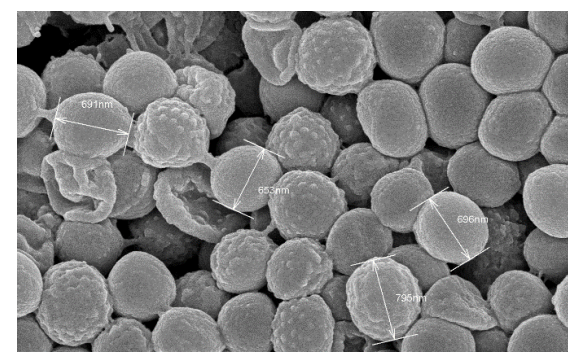

Figure 5. G2-1.2

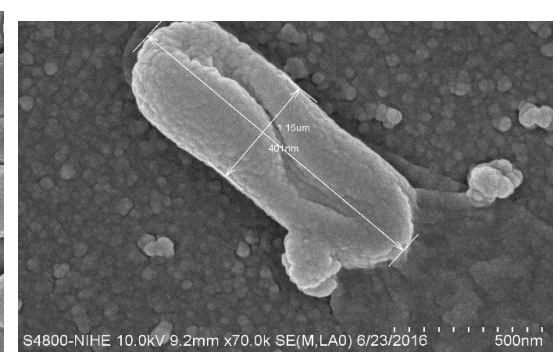

Figure 6. ST-SII2

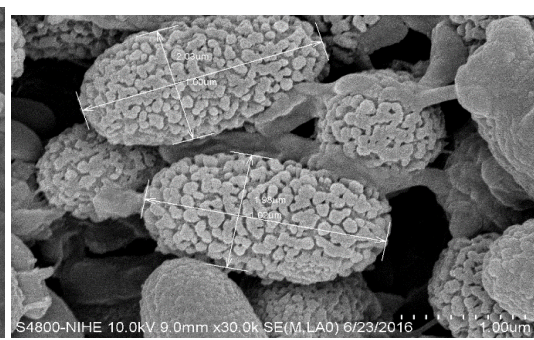

Figure 7. ST-SII4

\subsection{Liter culture of bacterial isolates}

Six isolates selected (B-1.1, B-1.3, B-2.2, G2-1.2, ST-SII 2 and ST-SII4) were co - cultured in 2-liter tanks with and without carriers for comparison and determination of bacterial growth under natural conditions. Culture system was maintained for 5 days before add the ammonium concentration to be at $5 \mathrm{mg} / \mathrm{l}$. The results are shown in Figure 8 .

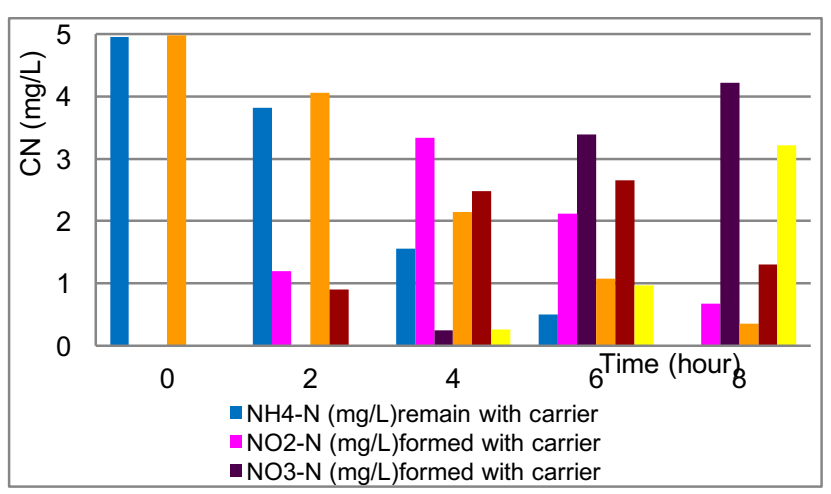

Figure 8. Activity of nitrifying bacteria with and without carriers

In both systems with and without carriers, concentration of ammonium remaining reduced significantly. However, with carriers, bacteria were able to eliminate $\mathrm{NH}_{4}^{+}$totally from liquid medium with higher efficiency. For instance, at 2 hour mark, ammonium elimination by bacteria on carriers was enhanced by 1.2 times, at 4 hour was 1.37 times and at 6 hour was 2.1 times. To observe less nitrite concentration in medium because it was converted in to nitrate concentration by nitrite oxidizing bacteria, so highest nitrate concentration in medium on the $8^{\text {th }}$ day.

\subsection{General characteristics of the genera and species of AOB}

The taxonomic framework of the AOB stems from early investigations of Winogradsky. The isolates originally were categorized into genera on the basis of the shape of cells and the arrangement of their intracytoplasmic membranes. Using these criteria, the genera Nitrosomonas, $\mathrm{Ni}$ trosococcus, Nitrosospira, Nitrosolobus and Nitrosovibrio have been established (Hans-Peter Koops et al., 2006). In the following, a brief listing of the distinguishing morphological features of the two recognized genera of AOB are Nitrosomonas and Nitrococcus compare with B-1.1 and G2-1.2 species. Differential characteristics of the genera of AOB and of B-1.1 and G2-1.2 species are presented in Tables 4. The result shown that, characteristics of G2-1.2 strain nearly with Nitrosococcus genus and B-1.1 strain nearly with Nitrobacter genus in preliminary classification based on characteristics and preferred habitats.

\section{Conclusion}

Isolated 16 bacterial strains that could grow on Winogradsky medium. In which, 10 strains oxidize ammonium to nitrite while 6 oxidize nitrite to nitrate. Six strains from both groups (B1.1, B1.3, B2.2, G2-1.2, ST-SII 2, ST-SII4) that show superior activity and biofilm forming capacity were selected for further studies.

Selected bacteria were co - cultured in 2 - liter tanks with and without carriers. The system with carriers $(30 \%$ of total volume) increased nitrogen elimination efficiency range from 1.2 to 2 times after 2 hours, 4 hours and 6 hours.

Two representatives of ammonia oxidizing bacterial group (B1.1; G2-1.2) were classification based on characteristics and they were classified as Nitrosomonas sp. and Nitrosococcus $\mathrm{sp}$.

\section{References}

[1] Alcaraz, G-., Chiappa-carrara, X., Espinoza, V., Vanegas, C., 1999. Acute toxicity of ammonia and nitrite to white shrimp Penaeus setfféms post larvae. $J$. World Aquacult. Soc. 30: 90-97.

[2] Atlas, R.M., 1995. Winogradsky's Medium, Modified, Hanbook of Media for Enironmental Microbiology. CRC Press Boca Raton: New York-London-Tokyo: 503 pp.

[3] Cavalli, R.O., Berghe, E.V., Lavens, P., Thuy, N.T.T., Wille, M., Sorgeloos, P., (2000). Ammonia toxicity as a criterion for the evaluation of larval quality in the prawn Macrobraclnwn rosenbergii. Comp. Biochem. Physiol. 125C: 333-343.

[4] Chen, J.C., Lee, Y., 1997. Effects of nitrite on mortality, ion regulation and acid base balance of Macrobrachium rosenbergii at different external chloride concentration. Aquat. Toxicol. 39: 291-305.

[5] Chen, S., Ling, J., Blancheton, J.P., 2006. Nitrification kinetics of biofilm as affected by water quality factors. Aquacult. Eng. 34: 179-197.

[6] Cheng, S.Y., Chen, J.C., (1995). Hemolymph oxygen content, oxyhemocyanin, protein levels and ammonia excretion in the shrimp Penaeus monodon exposed to ambient nitrite. Comp. Physiol. B. 164: 530-535. 
[7] Colt, J., Lamoureux, J., Patterson, R., Rogers, G., 2006. Reporting standards for biofilter performance studies. Aquacult. Eng. 34: 377-388.

[8] Eding. E.H., Kamstra, A., Verreth, J.A.J., I-Iuisman, E.A., Klapwijk, A., 2006. Design and operation of nitiifying trickling filters in recirculating aquaculture: A review. Aquacult. Eng. 34: 234-260.

[9] Fitch, M.W., Pearson, N., Richards, G., Burken, J.G., 1998. Biological fixed-film systems. Water Environ. Res. 70, 495-518.

[10] Forgie D. J. L. 1988. Development of a Leachate Treatment Selection Model. ASCE Environ. Eng. Natl. Conf. 875-882.

[11] Franson, M.A.H., 1995. Standard methods for the examiation of water and wastewater, Publication Office American Public Health Association-Washington, DC 20005, 19th Ed: 225-227; 240-243; 461-464.

[12] Fumkawa, K., Ike, A., Ryu, S.Fujita, M., 1993. Nitrification of NH4- $\mathrm{N}+$ polluted seawater by immobilized acclimated marine nitrifying sludge (AMNS). $J$. Perm. Bioeng. 76: 515-520.

[13] Golz, W.J., Rusch, K.A., Malone, R.F., 1999. Modeling the major limitations on nitrification in floatingbead filters. Aquacult. Eng. 20: 43-61.

[14] Greiner, A.D., Timmons, M.B., (1998). Evaluation of the nitrification rates of microbead and trickling filters in an intensive recirculating tilapia production facility. Aquacult. Eng. 18: 189-200.

[15] Gutierrez-Wing, M.T., Malone, R.F. 2006. Biological filters in aquaculture: Trends and research directions for freshwater and marine applications. Aquacult. Eng. 34: 163-171.

[16] Koops H-P., Pirkhold U., Pommerening-r., timmermann G., and Wagner M., 2006. The lithoautrophic Ammonia-Oxidizing Bacteria. Chapter 3.2.12 In Prokaryotes 5: 778-811.

[17] Jewell, W.J., Cummings, R.J., 1990. Expanded bed treatment of complete recycle aquaculture systems. Water Sci.Technol. 22: 443-450.

[18] Kamstra, A., van der Heul, J .W., Nijhof, M., 1998. Performance and optimization of trickling filters on eel farms. Aquacult. Eng. 17: 175-192.

[19] Liu, C.H., Chen, J.C., 2004. Effect of ammonia on the immune response of white shrimp Litopenaeus vannamei and its suscetibility to $\mathrm{Vib} / 1^{\prime} 0$ alginolyticus.Fish. Shellfish. Immunol. 16: 321-334.

[20] Mallasen, M., Valenti, W.C., Ismael, D., 2004. Effects of nitrate concentration on larval development of the giant river prawn, Macrobrachium rosenbergii. J. Appl. Aquacult. I4: 55 - 69.

[21] Malone, R.F., Beecher, L.E., 2000. Use of floating bead filters to recondition recirculating waters in warmwater aquaculture production systems. Aquacult. Eng. 22: 57-74.

[22] Malone, R.F., Pfeiffer, T.J., 2006. Rating fixed film nitrifying biofilters used in recirculating aquaculture systems. Aquacult. Eng. 34: 389-402.
[23] Martin Dworkin (Editor-in-Chief), Stanley Falkow, Eugene Rosenberg, Karl-Heinz Schleifer, Erko Stackebrandt (Editors) 2006, Volume 5, Proteobacteria: Alpha and Beta Subclasses. Third Edition. The Prokaryotes. A Handbook on the Biology of Bacteria

[24] Metcalf and Eddy, lnc., 1991. Wastewater Engineering, Treatment, Disposal, and Reuse, third ed. McGraw Hill 1nc., New York: 1334pp.

[25] Naqvi, A.A., Adhikari, S., Pillai, B.R., Sarangi, N., 2007. Effect of ammonia-N on Growth and feeding Macrobrachium rosenbergii (De-Man). Aquac. Res. 38: $847-851$.

[26] New, M.B., 2002. A manual for the culture of the giant river prawn (Macrobrachizma rosenbergii). FAO Fisheries Technical Paper. No. 428. FAO, Rome : $212 \mathrm{pp}$

[27] Nijhof, M., Bovendeur, J., 1990. Fixed film nitrification characteristics in seawater recirculation fish culture systems. Aquaculture 87: 133-143.

[28] Nogueira, R., Lazarova, V., Manem, J., Melo, L.F., 1998. Influence of dissolved oxygen on the nitrification kinetics in a circulating bed biofilm reactor. Bioprocess Eng. 19: 441-449.

[29] Ostrensky, A., Wasielesky, Jr.W., 1995. Acute toxicity of ammonia to various life stages of sao paulo shrimp, Penaeus paulensis Perez-Farfate, 1967. Aquaculture 132: 339-347.

[30] Piedrahita, R.H., 2003. Reducing the potential environmental impact of tank aquaculture effluents through intensification and recirculation. Aquaculture 226: 35-44.

[31] Reynolds, T. D. and Richards P.A. 1996. Unit Operations and Processes in Environmental Engineering nd

2 Edition. Boston, MA: PWS

[32] Sandu, S.1., Boardman, G.D., Watten, B.J., Brazil, B.L., 2002. Factors influencing the nitrification efficieney of tluidized bed filter with a plastic bead medium. Aquacult. Eng. 26: 41-59.

[33] Seo, J.K., Jung, 1.H., Kim, M.R., Kim, B.J., Nam, S.W., Kim, S.K., 2001. Nitrification performance of nitrifiers immobilized in PVA (polyvinyl alcohol) for a marine recirculating aquarium system. Aquacult. Eng. 24: 181-194.

[34] Shnel, N., Barak, Y., Ezer, T., Dafni, Z., van Rijn, J., 2002. Design and performance of a zero-discharge tilapia recirculating system. Aquacult. Eng.26:191203.

[35] Summerfelt, S.T., 2006. Design and management of conventional fluidized-sand biofilters. Aquacult. Eng. 34: 275-302.

[36] Sung-Koo, K., Kong, 1., Lee, B., Limseok, K., Lee, M.-G., Suh, K.H., 2000. Removal of ammonium -N from a recirculation aquaculture system using an immobilized nitrifier. Aquacult. Eng. 21:139-150.

[37] Tomasso, J .R., 1994. Toxicity of nitrogenous wastes to aquaculture animals. Rev. Fishery Sci. 2: 291-314. 
[38] Timmons, M.B., Ebeling, J.M.., Wheaton, F.W., Summerfelt, S.T., Vinci, B.J., 2001. Recirculating Aquaculture Systems. Cayuga Aqua Ventures, Ithaca, NY, USA: $650 \mathrm{pp}$.

[39] Valenti, W.C., Daniels, W., 2000. Recirculation hatchery systems and management. In: New, M.B., Valenti, W.C. (Eds) Freshwater prawn culture: the farming of Macrobrachimn rosenbergii. Blackwell Science, Oxford, England: 69-90.

[40] Wheaton, F.W., Hochheimer, J.N., Kaiser, G.E., Krones, M.J., 1991. Principles of biological filtration. Engineering Aspects of Intensive Aquaculture, Proceedings from the Aquaculture Symposium, lcthaca, NY, Cornell University, April 4-6.

[41] Wheaton, F.W., Hochheimer, J.N., Kaiser, G.E., Krones, M.J., Libey, G.S., Easter, C.C., 1994. Nitrification principles. In: Timmons, M.B., Losordo, T.M.
(Eds.), Aquaculture Water Reuse Systems: Engineering Design and Management. Elsevier, Amsterdam: 101-126.

[42] Yang, L., Chou, L.-S., Shieh, W.K., 2001. Biofilter treatment of aquaculture water for reuse applications. Wat. Res. (35), 1 3: 3097-3108.

[43] Yossi Tal, J., Watts, E.M., Schreier, S.B., Sowers, K.R., Schreier, H.J. 2003. Characterization of the microbial community and nitrogen transfonnation processes associated with moving bed bioreactors in a closed recirculated mariculture system. Aquaculture 215: 187-202. 